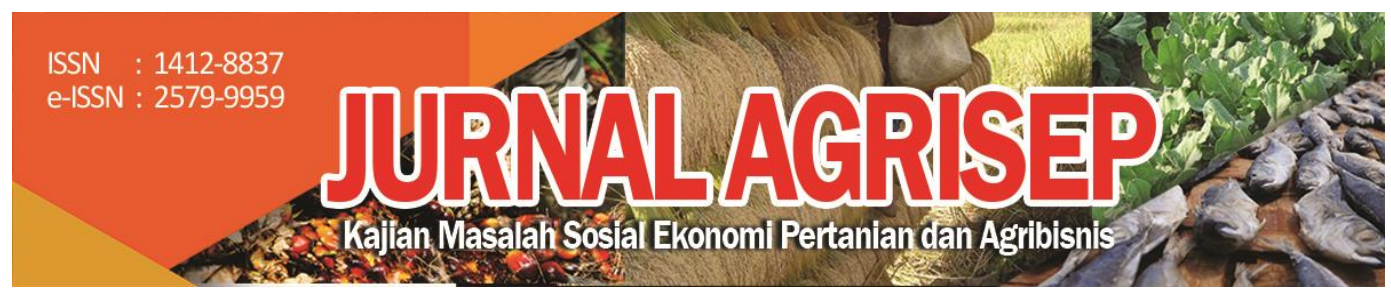

DOI: $10.31186 /$ jagrisep.19.2.301-314

\title{
PENGARUH AKSESIBILITAS PEMBIAYAAN TERHADAP PENDAPATAN PETANI KOPI DI LEMBAH GUMANTI, KABUPATEN SOLOK
}

\section{The effect of Financing Accesibility on Coffee Farmer income in Lembah Gumanti, Solok Regency}

\author{
Cindy Paloma1) ${ }^{1}$; Yusmarni'); Ami Sukma Utami ${ }^{3)}$, Hasnah ${ }^{4)}$ \\ 1,2,3,4)Jurusan Sosial Ekonomi Pertanian Fakultas Pertanian Universitas Andalas \\ Email: cindypaloma@gmail.com
}

\begin{abstract}
Capital is one of the most important factors for increasing coffee production. Coffee farmers accessibility to resources financing is still limited. Farmers are considered not bankable by financial institutions. This condition hampering them to manage and develope coffee farm. This study aims to : 1) analyze the characteristics of coffee farmer in the Lembah Gumanti District, 2) analyze factors that influence coffee farmers income in Lembah Gumanti District. The study was conducted in Solok Regency which is the largest coffee production in West Sumatra. This study using 30 samples of coffee farmers selected by simple random sampling method. Descriptive analysis and multiple regression analysis are used to answer the research question. Based on the results of descriptive analysis, the characteristics of coffee farmers is: farmer who in productive age with a low level of education, have family members ranged from 2-6 people, 90\% of coffee farmer have experience under 5 years, 93\% of coffe farmer capital comes from own capital and 3\% of coffe farmer capital from loan. Based on the multiple regression output, access to financial institutions, labor, farming experience, age, education, productivity, cost of farming, capital source, coffee bean prices and plants age variabels, simultaneously affected and significant to coffee farmers income. In Partial test, labor, number of trees, cost of farming and source of capital have a significant effect on coffee farmer income. The labor factor, the number of trees and the source of capital have a positive effect while the cost of farming has a negative effect. Farmer access to financial institutions is negative and not significant to income, because $63 \%$ of coffee farmers dont have access to financial institutions, and $36 \%$ of farmers who have access to financial institutions not using loan funds for farming, but for other needs, such as household consumption.
\end{abstract}

AGRISEP Vol. 19 No. 2 September 2020 Hal: 301 - 314| 301 
Keywords: accessibility, coffee, income

\begin{abstract}
ABSTRAK
Modal merupakan salah satu faktor yang penting dalam peningkatan produksi kopi. Aksesibilitas petani kopi terhadap sumber-sumber permodalan masih sangat terbatas. Hal ini dikarenakan petani dianggap tidak bankable oleh lembaga keuangan akibatnya menghambat petani kopi dalam mengelola dan mengembangkan usahataninya. Penelitian ini bertujuan: 1) menganalisis karakteristik petani kopi di Kecamatan Lembah Gumanti, 2) menganalisis faktor-faktor yang mempengaruhi pendapatan petani kopi di Kecamatan Lembah Gumanti. Penelitian dilakukan di Kabupaten Solok yang merupakan daerah penghasil kopi terbesar di Sumatera Barat. Terdapat 30 sampel petani kopi dalam penelitian ini, pengambilan sampel menggunakan metode simple random sampling. Untuk menjawab permasalahan penelitian digunakan analisis deskriptif dan analisis regresi berganda. Berdasarkan hasil analisis deskriptif, untuk tujuan satu, karakteristik petani kopi yang dilihat dari usia berada pada usia produktif dengan tingkat pendidikan rendah, jumlah anggota keluarga berkisar antara 2-6 orang, pengalaman berusaha tani kopi diatas 5 tahun sebesar 10\%, dibawah 5 tahun 90\%, sumber modal usahatani 3\% dari modal pinjaman, 93\% dari modal sendiri. Tujuan kedua, berdasarkan hasil regresi berganda secara simultan (bersama-sama) faktor akses lembaga keuangan, tenaga kerja, pengalaman usahatani, usia, pendidikan, produktivitas, biaya usahatani, modal awal, harga biji kopi dan umur tanaman kopi berpengaruh signifikan terhadap pendapatan usahatani kopi. Pengujian secara parsial, hanya faktor tenaga kerja, jumlah pohon, biaya usahatani dan modal awal berpengaruh signifikan terhadap pendapatan usahatani kopi. Faktor tenaga kerja, jumlah pohon dan modal awal berpengaruh positif sedangkan biaya usahatani berpengaruh negatif. Faktor akses petani pada lembaga keuangan berpengaruh negatif dan tidak signifikan, hal ini dikarenakan $63 \%$ petani kopi tidak memiliki akses pada Lembaga Keuangan, dan 36\% petani yang memiliki akses pada lembaga keuangan tidak sepenuhnya menggunakan dana pinjaman untuk usahatani, melainkan untuk kebutuhan lain, seperti konsumsi rumah tangga.
\end{abstract}

Kata kunci: aksesibilitas, kopi, pendapatan

\title{
PENDAHULUAN
}

Sektor pertanian, kehutanan, dan perikanan mempunyai peranan yang cukup penting dalam kegiatan perekonomian di Indonesia, hal ini dapat dilihat dari kontribusinya terhadap Produk Domestik Bruto (PDB) yang cukup besar yaitu sekitar 13,14\% pada tahun 2017 atau merupakan urutan kedua setelah sektor Industri Pengolahan. Salah satu sub sektor yang cukup besar potensinya adalah sub sektor perkebunan. Kontribusi sub sektor perkebunan dalam PDB yaitu sekitar 3,47\% pada tahun 2017 atau merupakan urutan pertama di sektor Pertanian, Peternakan, Perburuan dan Jasa Pertanian. Sub sektor ini merupakan penyedia bahan baku untuk sektor industri, penyerap tenaga kerja, dan penghasil devisa (BPS, 2017).

302 | Cindy Paloma, Yusmarni, Ami Sukma Utami, Hasnah; Aksesibilitas... 
Kopi merupakan salah satu produk perkebunan yang menjadi komoditas ekspor dengan nilai ekonomis yang relatif tinggi di pasaran dunia (Supriyadi, dkk, 2014). Ekspor Kopi alam Indonesia menjangkau lima benua yaitu Asia, Afrika, Australia, Amerika, dan Eropa. Pada tahun 2016, lima besar negara pengimpor Kopi alam Indonesia adalah United States, Jerman, Malaysia, Italy, dan Russia. Volume ekspor ke Unites States mencapai 63,253 ribu ton atau $13,52 \%$ dari total volume ekspor kopi Indonesia dengan nilai US\$256,466 juta. Peringkat kedua adalah Jerman, dengan volume ekspor sebesar 44,74 ribu ton atau 9,56\% dari total volume kopi Indonesia dengan nilai US\$ 104,021 juta. Peringkat ketiga adalah Malaysia, dengan volume ekspor sebesar 43,151 ribu ton atau 9,22\% dari total volume ekspor kopi Indonesia dengan nilai US\$ 86,968 juta. Peringkat keempat adalah Italy dengan volume ekspor 38,1 ribu ton atau sekitar 8,15\% dari total volume ekspor kopi Indonesia dengan nilai US\$ 79,655 juta. Peringkat kelima adalah Russia dengan volume ekspor 36,92 ribu ton atau 7,89 persen dari total volume ekspor Kopi alam dengan nilai US\$ 75,564 juta (data BPS, 2017).

Menurut data BPS (2017) produksi kopi di Indonesia menurut status pengusahaannya berasal dari perusahaan Perkebunan Negara sebesar 2,17\%, Perusahaan Perkebunan Swasta sebesar 2,37\% dan Perkebunan Rakyat (PR) sebesar $95 \%$. Hal ini mengindikasikan banyaknya petani yang menggantungkan hidupnya dari perkebunan kopi. Pulau Sumatera merupakan daerah penghasil tanaman kopi paling banyak di Indonesia dibandingkan dengan pulau-pulau lainnya. (Farmasari, 2018).

Salah satu jenis kopi yang dikembangkan dan menjadi komoditas ekspor adalah jenis kopi Arabika (Coffea arabica). Kopi Arabika mempunyai kualitas, cita rasa, dan harga relatif lebih tinggi dibandingkan dengan jenis kopi lainnya (Putri, dkk 2017). Kabupaten Solok merupakan salah satu daerah penghasil kopi arabika terbesar di Provinsi Sumatera Barat, menurut data BPS (2019) produksi kopi arabika 872,2 ton, nilai produktivitas kopi arabika pada tahun 2018 mencapai $823,2 \mathrm{~kg} / \mathrm{Ha}$ dengan luas tanam tanaman yang telah menghasilkan sebesar 1059,5 Ha dan belum menghasilkan sebesar 529,5 Ha, tanaman yang tua/rusak seluas 227,5 Ha. Wujud produksi kopi arabika dalam bentuk biji kering. Kecamatan Lembah Gumanti merupakan daerah penghasil kopi arabika terbesar di kabupaten Solok, dimana pada tahun 2018 luas tanam sebesar 282,5 Ha dan produksi mencapai 135 ton.

Pengusahaan kopi di Lembah Gumanti didominasi 90\% oleh perkebunan rakyat. Menurut Putri, dkk (2017) tanaman kopi di Lembah Gumanti sebagian besar belum memasuki masa produktivitas maksimal, rata-rata produksi kopi petani di Lembah Gumanti pada tahun 2017 sebesar $616 \mathrm{~kg}$. Produksi yang rendah akan berpengaruh pada pendapatan dan kesejahteraan petani. Penggunaan input produksi yang belum maksimal seperti pupuk dan pestisida menjadi hambatan dalam usahatani kopi. Modal merupakan faktor yang 
signifikan mempengaruhi produksi kopi di Lembah Gumanti (Putri, dkk 2017). Hasil penelitian Dewi \& Yuliarni (2017) juga menyatakan variable modal dan tenaga kerja berpengaruh positif terhadap jumlah produksi kopi arabika di KEcamatan Kintamani. Penelitian Yourdy (2017) juga menunjukkan faktor modal dan luas lahan berpengaruh positif terhadap produksi kopi arabika di Sulawesi Selatan. Modal bisa berasal dari modal sendiri atau berasal dari pinjaman pada Lembaga Keuangan.

Di lembah Gumanti terdapat koperasi Solok Radjo yang membantu petani dalam hal produksi dan pemasaran kopi, namun memiliki keterbatasan pendanaan dalam memberikan pelayaan pinjaman bagi anggotanya. Lembaga Keuangan formal yang ada seperti Bank Rakyat Indonesia (BRI), namun, tidak banyak petani yang mengakses Lembaga keuangan ini karena tanaman kopi masih tergolong muda, sehingga produksinya belum optimal. Selain dari masalah keterbatasan akses permodalan, menurut Supriyadi (2014) upaya untuk meningkatkan pendapatan dan kesejahteraan petani sering dihadapkan pada permasalahan pengetahuan petani yang relatif rendah, lahan garapan yang sempit serta kurangnya keterampilan petani yang nantinya akan berpengaruh pada pendapatan petani.

Dari permasalah tersebut, penelitian ini bertujuan untuk mengetahui karakteristik petani kopi dan menganalisis faktor- faktor yang mempengaruhi pendapatan petani kopi di Kecamatan Lembah Gumanti. Penelitian ini secara khusus ingin melihat pengaruh aksesibilitas petani kopi pada Lembaga keuangan dan pengaruhnya terhadap pendapatan, selain itu juga melihat faktorfaktor produksi dan harga. Hal ini penting untuk dilakukan agar petani kopi termotivasi untuk meningkatkan produksi kopi dalam rangka pemenuhan ekspor dan kebutuhan dalam negri serta mecapai kesejahteraan dengan berusahatani kopi rakyat.

\section{METODE PENELITIAN}

Penelitian dilakukan di Kabupaten Solok Provinsi Sumatera Barat. Kabupaten Solok dipilih secara sengaja (purposive), karena daerah ini menjadi daerah penghasil kopi terbesar di Sumatera Barat (BPS, 2019). Metode yang digunakan adalah metode survei pada Kecamatan Lembah Gumanti Kabupaten Solok. Pengambilan sampel dilakukan secara simple random sampling (acak sederhana) terhadap 30 petani kopi yang mengakses kredit di lembaga keuangan dan tidak mengakses kredit. Data yang dikumpulkan adalah data primer dan data sekunder melalui wawancara dan pengamatan langsung dengan panduan alat wawancara berupa daftar pertanyaan.

Analisis statistik deskriptif dalam penelitian ini digunakan untuk menggambarkan karakteristik petani kopi di Kecamatan Lembah Gumanti, yang dilihat dari umur petani, jumlah tanggungan keluarga, pengalaman lama berusaha tani, tingkat pendidikan, sumber modal dengan menggunakan hasil

304 | Cindy Paloma, Yusmarni, Ami Sukma Utami, Hasnah; Aksesibilitas... 
persentase. Selain itu penelitian ini juga menggunakan analisis regresi berganda untuk menjawab faktor-faktor yang mempengaruhi pendapatan petani kopi di Lembah Gumanti. Variabel yang digunakan dalam model ini adalah $\mathrm{Y}=$ pendapatan petani kopi (PP), X1 = akses ke Lembaga keuangan (dummy $1=$ akses, $0=$ tidak akses) $(\mathrm{ACC}=1, \mathrm{TAC}=0), \mathrm{X} 2=$ jumlah tenga kerja yang digunakan (orang) (TK), $\mathrm{X} 3=$ jumlah pohon kopi (batang) (JPK), $\mathrm{X} 4=$ pengalaman usahatani kopi (tahun) (PUTK), X5 =usia petani (tahun) (UP), $\mathrm{X} 6=$ Pendidikan (tahun) (PDD), X7= Produktivitas kopi (kg) $(\mathrm{PVK}), \mathrm{X} 8=$ biaya usahatani (Rupiah) (BUTK), $X 9=$ modal awal yang digunakan (Rupiah) (MAK), $\mathrm{X} 10=$ harga biji kopi (Rupiah/kg) $(\mathrm{HBK}), \mathrm{B} 0=$ Konstanta,$\beta \mathrm{i}=$ Parameter, estimasi, $i=1,2,3, \ldots, 10$, ei $=$ Error term

Data yang telah dikumpulkan selanjutnya diolah menggunakan software SPSS 20.0 for windows dan ouput hasil pengolah diuji secara statistik dilakukan dengan melihat nilai koefisien determinasi atau nilai (R2), uji $F$ dan uji t. Uji $F$ dilakukan untuk melihat pengaruh semua variabel indenpenden secara bersama-sama terhadap variabel pendapatan dengan kriteria jika $\mathrm{F}$ hitung $>\mathrm{F}$ tabel, maka variabel independen berpengaruh secara signifikan terhadap variabel dependen dengan F tabel: $\mathrm{Fa}(\mathrm{k}-1 ; \mathrm{n}-\mathrm{k})$ 2) pada Level of Significance $(\alpha)=$ 0,05 . Uji $t$ dilakukan untuk melihat pengaruh masing-masing variabel independen terhadap variabel pendapatan secara parsial dengan kriteria jika $t$ hitung >tabel, berarti variabel tersebut memiliki pengaruh secara signifikan terhadap variabel dependen pada level of Signifi-cance $(\alpha)=0,05$ ttabel: ta / 2(nk).

\section{HASIL DAN PEMBAHASAN}

\section{Karakterisitik Petani Kopi Arabika di Lembah Gumanti}

\section{Umur Petani Kopi}

Menurut UU No. 13 tahun 2003 usia produktif berkisar dari umur 15-64 tahun. Menurut S. L. Neonbota \& S. J. Kune (2016) kinerja seseorang dapat dipengaruhi oleh faktor umur. Usia yang produktif tentu akan memberikan kemudahan dalam mengusahakan usahatani. Jika umur petani semakin tua maka akan berpengaruh pada kemampuan petani tersebut. Umur menurut tingkat produktifitasnya terbagi atas 3 yakni usia belum produktif, usia produktif dan usia tidak produktif. Kelompok umur petani kopi di Lembah Gumanti tergolong pada usia produktif antara 20- 65 tahun.

\section{Jumlah Tanggungan Keluarga}

Jumlah tanggungan keluarga petani merupakan jumlah anggota keluarga yang dibiayai oleh petani, berupa kebutuhan sandang, pangan dan papan. Rata-rata jumlah tanggungan keluarga petani kopi di Lembah Gumanti 
berkisar 2-6 orang,anggota keluarganya masih berada pada usia sekolah/pendidikan tinggi. Menurut S. L. Neonbota \& S. J. Kune (2016) semakin tinggi tanggungan keluarga petani semakin besar pengeluaran petani. Hal ini didukung oleh hasil penelitian Widyawati (2013) bahwa jumlah tanggungan keluarga juga mempengaruhi curahan jam kerja wanita tani, karena jika jumlah anak dan tanggungan semakin besar, maka biaya yang dikeluarkan untuk kebutuhan sehari-hari juga semakin tinggi dan biaya sekolah yang relatif mahal.

Tabel 1. Karakteristik Petani Kopi Arabika di Kecamatan Lembah Gumanti

\begin{tabular}{|c|c|c|c|}
\hline No & Karakteristik & Jumlah petani & Persentase \\
\hline \multirow[t]{7}{*}{1} & Umur (tahun) & & \\
\hline & $20-30$ & 4 & 13,33 \\
\hline & $31-40$ & 3 & 10,00 \\
\hline & $41-50$ & 6 & 20,00 \\
\hline & $51-60$ & 11 & 36,67 \\
\hline & $>61$ & 6 & 20,00 \\
\hline & Jumlah & 30 & 100,00 \\
\hline \multirow[t]{6}{*}{2} & Jumlah Tanggungan Keluarga (orang) & & \\
\hline & $0-1$ & 15 & 15,00 \\
\hline & $2 \mathrm{~s} / \mathrm{d} 3$ & 8 & 8,00 \\
\hline & $4 \mathrm{~s} / \mathrm{d} 5$ & 5 & 5,00 \\
\hline & $6 \mathrm{~s} / \mathrm{d} 7$ & 2 & 2,00 \\
\hline & Jumlah & 30 & 100,00 \\
\hline \multirow[t]{5}{*}{3} & Pengalaman Usahatani (tahun) & & \\
\hline & $<5$ & 27 & 90,00 \\
\hline & $6 \mathrm{~s} / \mathrm{d} 10$ & 2 & 6,67 \\
\hline & $11 \mathrm{~s} / \mathrm{d} 30$ & 1 & 3,33 \\
\hline & Jumlah & 30 & 100,00 \\
\hline \multirow[t]{7}{*}{4} & Tingkat Pendidikan & & \\
\hline & Tidak Tamat SD & 6 & 20,00 \\
\hline & SD & 9 & 30,00 \\
\hline & SMP & 5 & 16,67 \\
\hline & SMA & 9 & 20,00 \\
\hline & DI-D3/S1 & 1 & 3,33 \\
\hline & Jumlah & 30 & 100,00 \\
\hline \multirow[t]{4}{*}{5} & Sumber Modal & & \\
\hline & Modal Sendiri & 28 & 93,33 \\
\hline & Modal Pinjaman & 2 & 6,67 \\
\hline & Jumlah & 30 & 100,00 \\
\hline
\end{tabular}

Sumber: Data Primer Diolah, 2019

306 | Cindy Paloma, Yusmarni, Ami Sukma Utami, Hasnah; Aksesibilitas... 


\section{Pengalaman Usahatani Kopi Arabika}

Pengalaman berusahatani kopi petani di Lembah Gumanti mulai dari 130 tahun, dimana 90 persen petani memiliki pengalaman berusahatani kopi Arabika selama kurang dari 5 tahun. Pengalaman usahatani ini seiring dengan umur tanaman kopi Arabika yang paling tinggi berumur 5 tahun.

\section{Tingkat Pendidikan Petani Kopi Arabika}

Tingkat Pendidikan petani kopi tergolong rendah, 67 persen berpendidikan dibawah SMP, tingkat Pendidikan akan mempengaruhi pola pikir petani dalam mengadopsi pengetahuan. Semakin tinggi tingkat Pendidikan maka daya serap akan makin luas (S. L. Neonbota \& S. J. Kune 2016). Pendidikan yang rendah, selain berimplikasi pada kurang terkoordinirnya perencanaan pertanian, juga akan berpengaruh pada jenis pekerjaan lain yang dapat dilakukan oleh petani dalam upaya peningkatan pendapatan (Dewi, dkk, 2018).

\section{Sumber Permodalan Usahatani Kopi Arabika}

Hampir keseluruhan petani kopi Arabika, menggunakan modal sendiri dalam pembudiayaan, mulai dari pengolahan lahan, panen dan upah tenaga kerja yang digunakan. Koperasi Solok Radjo merupakan koperasi yang berada di Lembah Gumanti, memberikan bibit kopi gratis bagi petani kopi, hal ini mengurangi modal yang dikeluarkan oleh petani kopi untuk usahataninya .

\section{Faktor-Faktor Yang Mempengaruhi Pendapatan Petani Kopi Arabika}

Koefisien determinasi ialah besarnya variabel keragaman variabel terikat (Y) yang mampu dijelaskan seluruh variabel bebas (X) dalam model. Nilai koefisien determinasi $\left(\mathrm{R}^{2}\right)$ diperoleh sebesar 0.656 , hal ini berarti sebesar $65,6 \%$ variable dependen pendapatan petani kopi bisa dijelaskan oleh variable independent yaitu akses lembaga keuangan, tenaga kerja, jumlah pohon kopi, pengalaman usahatani, usia petani, pendidikan, produktivitas rata-rata, biaya usahatani, modal awal, harga biji dan umur kopi. Sisanya sebesar $34,4 \%$ dijelaskan oleh variabel-variabel lain diluar model.

Nilai uji $\mathrm{F}$ dihitung untuk mengetahui apakah variable terikat secara simultan (bersama-sama) berpengaruh terhadap pendapatan petani. Nilai $F$ merupakan perbandingan antara rata-rata kuadrat regresi dan kuadrat residu. Hasil penelitian menunjukkan, nilai $F_{\text {hitung }}>F_{\text {tabel }}(3,615>2,34)$ pada taraf nyata $5 \%$, artinya variabel akses lembaga keuangan, tenaga kerja, jumlah pohon kopi, pengalaman usahatani, usia petani, pendidikan, produktivitas rata-rata, biaya usahatani, modal awal, harga biji dan umur kopi secara simultan berpengaruh terhadap pendaptan petani kopi. 
Tabel 2. Hasil analisis regresi berganda faktor-faktor yang mempengaruhi pendapatan petani kopi di Kecamatan Lembah Gumanti

\begin{tabular}{|c|c|c|c|c|}
\hline Model & Variabel & Koefisien & t_statistik & Prob \\
\hline Konstanta & & - 3345933,502 & & \\
\hline $\mathrm{X}_{1}$ & Akses ke Lembaga Keuangan & $-5391923,889$ & $-1,138$ & 0,269 \\
\hline$X_{2}$ & Tenaga Kerja & 1142051,586 & 2,843 & $0,010 * *$ \\
\hline $\mathrm{X}_{3}$ & Jumlah Pohon & 3483,398 & 1,520 & $0,145^{* * *}$ \\
\hline $\mathrm{X}_{4}$ & Pengalaman usahatani & $-481279,031$ & $-0,424$ & 0,677 \\
\hline $\mathrm{X}_{5}$ & Usia petani & 148637,228 & 0,768 & 0,452 \\
\hline $\mathrm{X}_{6}$ & Pendidikan & 124817,379 & 0,203 & 0,841 \\
\hline $\mathrm{X}_{7}$ & Produktivitas rata-rata & $-5208,865$ & $-0,154$ & 0,879 \\
\hline $\mathrm{X}_{8}$ & Biaya usahatani & $-14,687$ & $-2,974$ & $0,008^{*}$ \\
\hline $\mathrm{X}_{9}$ & Modal awal & 0,443 & 3,354 & $0,003 *$ \\
\hline $\mathrm{X}_{10}$ & Harga Biji & 672,485 & 0,119 & 0,907 \\
\hline & $\begin{array}{l}\mathrm{F} \text { hitung }=3.615 \\
\mathrm{R} \text { square }=0.656 \\
\text { Pendapatan }\end{array}$ & & & \\
\hline
\end{tabular}

Sumber: Data Primer Diolah, 2019

Keterangan: * signifikan pada taraf nyata 1 persen, ${ }^{* *}$ signifikan pada taraf nyata 5 persen, ${ }^{* * *}$ signifikan pada taraf nyata 15 persen

Analisis yang digunakan pada penelitian ini adalah analisis regresi berganda. Model matematis fungsi pendapatan dengan metode Ordinary Least Square (OLS). Analisis regresi berganda digunakan untuk menguji pengaruh antara variabel independen terhadap pendapatan petani kopi arabika di Lembah Gumanti. Berdasarkan hasil regresi linear berganda, maka dapat dibentuk model persamaan regresi berganda sebagai berikut:

$$
\begin{aligned}
Y= & -3345933,502-5391923.889 X_{1}+1142051.586 X_{2}+3483.398 X_{3}- \\
& 481279.031 X_{4}+148637.228 X_{5}+124817.379 X_{6}-5208.865 X_{7}-14.687 X_{8} \\
& +0.443 X_{9}+672.485 X_{10}
\end{aligned}
$$

Nilai uji t (parsial) pada dasarnya menunjukkan seberapa jauh pengaruh suatu variabel penjelas secara individual dalam menerangkan variasi variabel terikat. Variabel yang signifikan pada pada taraf nyata 0,001 adalah biaya usahatani dan modal awal, dengan nilai probabilitas sebesar 0,008 dan 0,003. Variabel tenaga kerja signifikan pada taraf nyata 0,05 dengan nilai probabilitas sebesar 0,010 . Variabel yang signifikan pada taraf nyata 0,015 adalah variabel jumlah pohon dengan nilai probabilitas sebesar 0,0145. Variabel akses lembaga keuangan, pengalaman usahatani, usia, pendidikan, produktivitas dan harga biji kopi tidak berpegaruh signifikan terhadap pendapatan petani kopi pada taraf

308 | Cindy Paloma, Yusmarni, Ami Sukma Utami, Hasnah; Aksesibilitas... 
nyata 0,05 persen. Variabel tenaga kerja, jumlah pohon, usia petani, pendidikan, modal awal dan harga biji berpengaruh positif terhadap pendapatan. Hal ini menunjukkan bahwa setiap penambahan penggunaan variabel-variabel tersebut akan meningkatkan pendapatan petani kopi. Nilai koefisien variable tenaga kerja sebesar 1142051.586, artinya jika penggunaan tenaga kerja ditingkatkan 1 orang, sedangkan variable lain dianggap konstan maka pendapatan petani kopi akan naik sebesar Rp. 1.142.051,586. Pada variable jumlah pohon, jika pohon ditambah 1 batang maka pendapatan petani akan bertambah sebesar Rp. $3.483,398$ dengan variable lain dianggap konstan. Nilai koefisien usa petani sebesar 148637.228, artinya jika usia petani bertambah 1 tahun maka pendapatan petani akan meningkat sebesar Rp. 148637.228, jika variable lain dianggap konstan.

Nilai koefisien pendidikan petani adalah 124817.379 , artinya jika terjadi peningkatan tahun pendidikan sebesar 1 tahun akan meningkatkan pendapatan petani sebesar Rp. 124817.379. Variabel modal awal usahatani memiliki nilai koefisien sebesar 0,443, artinya jika terjadi peningkatan modal awal sebesar Rp. 1 akan meningkatkan pendapatan masyarakat sebesar Rp. 0,443. Hasil regresi untuk variable harga jual biji kopi menunjukkan nilai koefisien sebesar 672.485, artinya jika terjadi peningkatan harga biji kopi sebesar Rp. 1 maka akan meningkatkan pendapatan sebesar Rp. 672.485, jika variable lain dianggap konstan.

Variabel akses ke Lembaga keuangan, pengalaman usahatani, produktivitas rata-rata dan biaya usahatani berpengaruh negatif terhadap pendapatan usahatani kopi. Hal ini mengakibatkan setiap penambahan satusatuan variable tersebut akan menurunkan pendapatan. Nilai koefisien dari akses petani ke Lembaga keuangan adalah 5391923.889, artinya setiap akses yang dimiliki petani ke Lembaga keuangan maka akan menurunkan pendapatan petani sebesar 5391923.889. Nilai pengalaman berusahatani jika bertambah 1 tahun maka akan menurunkan pendapatan petani sebesar Rp. 481279.031. Variabel produktivitas rata-rata memiliki koefisien sebesar 5208.865, jika terjadi peningkatan produktivitas maka akan menurunkan pendapatan petani kopi sebesar Rp. 5208.865. Nilai koefisien biaya usahatani adalah 14.687, artinya jika terjadi peningkatan biaya usahatani sebesar Rp. 1 akan menurunkan nilai pendapatan sebesar Rp. 14.687 jika variable lain dianggap konstan.

Akses ke Lembaga keuangan, berpengaruh negatif pada pendapatan petani, namun tidak signifikan. Hal ini disebabkan dari 30 sampel responden, hanya 11 orang yang mengakses Lembaga keuangan. Tujuan akses adalah memperoleh pembiayaan untuk produksi seperti pembelian pupuk dan membayar upah tenaga kerja. Namun kondisi pengamatan dilapangan banyak petani di Lembah Gumanti yang menggunakan pembiayaan digunakan untuk konsumsi seperi kebutuhan Rumah Tangga dan kebutuhan pendidikan anak. Hal ini disebabkan karna pendapatan dari hasil panen kopi tidak mencukupi 
kebutuhan konsumsi. Petani yang tidak mengakses Lembaga keuangan memiliki tingkat pendapatan rendah < Rp. 5.000.000/tahun. Hal ini sejalan dengan penelitian Sartika (2018) bahwa petani kopi di Pangalengan yang tidak melakukan akses kredit terbanyak memiliki pendapatan kurang dari Rp5.000.000,00 dengan persentase $61,11 \%$ dari total responden yang tidak melakukan akses kredit.

Tenaga kerja, berpengaruh positif dan signifikan mempengaruhi pendapatan petani kopi. Tenaga kerja digunakan mulai dari pengolahan lahan sampai pada proses pemanenan. Tenaga kerja yang digunakan petani berasal dari tenaga kerja dalam keluarga (TKDK) dan tenaga kerja luar keluarga (TKLK). Rata-rata responden menggunakan kurang lebih 8 orang tenaga kerja, tambahan tenaga kerja umumnya dilakukan pada proses pemanen buah kopi. Menurut Mankiw (2000) penggunaan tenaga kerja yang optimal dapat meningkatkan hasil dari proses produksi sehingga dapat meningkatkan pendapatan.

Jumlah pohon kopi berpengaruh positif dan signifikan meningkatkan pendapatan petani kopi. Hal ini sesuai dengan hasil penelitian Istianah (2015) bahwa jumlah pohon kopi berpengaruh sangat nyata terhadap pendapatan petani kopi di Kecamatan Jambu Kabupaten Semarang. Dari hasil penelitian di Lembah Gumanti rata-rata jumlah pohon kopi dari 30 sampel sebanyak 1.250 batang, dengan $60 \%$ tanaman yang menghasilkan dan 30\% terdiri dari tanaman yang belum menghasilkan. Apabila semakin besar jumlah pohon kopi yang dimilki petani maka semakin tinggi produksinya dan semakin meningkat pendapatan petani.

Pengalaman usahatani kopi berpengaruh negatif terhadap pendaptan usahatani kopi. Hal ini sesuai dengan hasil penelitian Putri dkk (2018), petani di Lembah Gumanti selama ini petani mengusahakan jenis kopi robusta, bukan jenis kopi arabika. Hal ini menyebabkan pengalaman usahatani tidak meningkatkan produksi yang akhirnya tidak meningkatkan pendapatan petani. Menurut Putri (2018), dalam kegiatan teknis pemeliharaan tanaman kopi, petani tidak melakukan pemeliharaan sesuai dengan anjuran untuk menghasilkan produksi yang baik, walaupun sudah mengetahui bagaimana teknis pemeliharaan tersebut. Bahkan, petani sebenarnya sudah mengetahui konsekuensi dari kegiatan tersebut, namun petani tidak melakukan hal tersebut mengingat akan ada tambahan biaya yang akan dikeluarkan jika melakukan pemeliharaan secara intensif. Seperti adanya tambahan biaya tenaga kerja untuk pemangkasan yang dilakukan secara rutin yang mengurangi keuntungan yang diperoleh petani.

Usia petani pada penelitian ini berpengaruh positif terhadap pendapatan petani. Semakin bertambahnya usia semakin meningkat tingkat pendapatan petani. Hal ini tidak sejalan dengan teori Soekartawi (2002) yang menyatakan bahwa pada umumnya petani yang berumur relatif muda dan sehat mempunyai kemampuan fisik lebih besar, lebih cepat menerima hal-hal baru yang 
dianjurkan, berjiwa dinamis dan berani menanggung resiko, sehingga semakin tinggi umur petani maka akan menurunkan pendapatan usahatani, hal ini disebabkan karena rata-rata umur petani responden di Lembah Gumanti masih berusia umur produktif $20-60$ tahun.

Tingkat Pendidikan petani berpengruh positif dalam meningkatkkan pendapatan. Hasil ini didukung oleh penelitian Istianah (2015), bahwa variabel Pendidikan berpengaruh positif terhadap pendapatan. Pendidikan sangat mempengaruhi sikap dan pola fikir petani. Semakin tinggi Pendidikan yang ditempuh akan semakin mudah menerima informasi baru serta teknologi maju dan mudah mengases untuk memperluas hubungan, cara mengolah hasil dan pemasaran.

Produktivitas rata-rata kopi berpengaruh negatif terhadap pendapatan kopi. Produktivitas dipengaruhi oleh luas lahan dan produksi kopi arabika. Menurut Putri (2018) tanaman kopi di Lembah Gumanti yang dimiliki petani sebagian besar belum memasuki masa produktivitas maksimal. Hal ini disebabkan belum optimalnya penggunaan faktor-faktor produksi seperti penggunaan pupuk yang belum optimal, sehingga menurunkan produktivitas dan berdampak pada turunnya pendapatan petani.

Biaya usahatani berpengaruh negatif dan signifikan menurunkan pendapatan petani. Menurut Sukirno (2003) terdapat pengaruh biaya produksi dengan pendapatan petani yaitu jika biaya produksi semakin tinggi, maka pendapatan petani akan menurun, jika penggunaan produksi sedikit maka pendapatan petani juga akan meningkat. Penurunan pendapatan terhadap penggunaan biaya yang tinggi karena tanaman kopi belum berproduksi optimal. Biaya produksi yang dikeluarkan oleh petani kopi tergantung dari luas lahan yang dikelola untuk tanaman kopi dalam sekali panen, alokasi biaya produksi meliputi upah tenaga kerja dimusim panen, dan pembelian pupuk. Upah tenaga kerja rata-rata dikeluarkan sebesar Rp. $75.000 / \mathrm{HOK}$, dan pembelian pupuk berkisar antara RP. 2.000 - 7.000 / kg, pupuk yang digunakan adalah pupuk urea, SP 36, KCL dan Ponska sedangkan pupuk organik yang digunakan adalah arang kayu dan kotoran ternak. Frekuensi pemberiann pupuk oleh petani di Lembah Gumanti dilakukan 1 kali dalam 3 bulan - 6 bulan. Berbeda halnya dengan penelitian penelitian Farmasari (2018) dimana variabel biaya produksi, biaya produksi berpengaruh positif terhadap pendapatan petani kopi di Kabupaten Bener Meriah jika biaya produksi meningkat sebesar 1 rupiah maka pendapatan petani kopi akan meningkat sebesar Rp 1.777.696,698.

Modal awal yang digunakan petani berpengaruh positif dan signifikan meningkatkan pendapatan petani kopi. Modal awal petani kopi 90 persen berasal dari tabungan sendiri, modal awal yang dikeluarkan oleh petani kopi di Lembah Gumanti sebesar Rp. 4.000 .000 - Rp. 5.000.000 pada awal musim tanam. Modal yang digunakan untuk pembelian bibit dan peralatan usahatani, namun saat ini koperasi solok Radjo memberikan bibit kopi gratis kepada petani di 
lingkungan Lembah Gumanti. Harga bibit mulai dari Rp. 2.000, menurut Putri dkk (2018) varietas kopi yang digunakan adalah jenis Andungsari 1. Varietas ini memiliki pertumbuhan kate, buah masak yang kurang serempak, berbunga pertama pada umur 15-24 bulan, rentan terhadap penyakit karat daun serta cita rasa jenis ini baik.

Harga jual biji kopi berpengaruh positif namun tidak signifikan dalam meningkatkan pendapatan petani kopi. Kopi Arabika mempunyai kualitas, cita rasa, dan harga relatif lebih tinggi dibandingkan dengan jenis kopi lainnya (BPS Provinsi Sumatera Barat, 2014). Petani di Lembah Gumanti menjual kopi dalam bentuk biji (cherry) dengan kisaran harga jual Rp. 6.000 - Rp. 10.000/ kg kepada pedagang pengumpul atau Koperasi Solok Radjo berdasarkan harga jual tertinggi. Semakin tinggi harga jual maka pendapatan petani juga semakin tinggi. Harga yang tinggi akan meningkatkan minat petani untuk melakukan penanaman kopi (Audrey, dkk 2018).

\section{SIMPULAN DAN SARAN}

\section{Simpulan}

Analisis karakteristik petani kopi arabika di Kecamatan Lembah Gumanti yang dilihat dari usia berada pada usia produktif dengan tingkat pendidikan rendah, jumlah anggota keluarga berkisar antara 2-6 orang per keluarga, pengalaman berusaha tani kopi diatas 5 tahun sebesar 10\%, dibawah 5 tahun $90 \%$, sumber modal usahatani $3 \%$ dari modal pinjaman, $93 \%$ berasal dari modal sendiri.

Berdasarkan hasil regresi berganda secara simultan (bersama-sama) faktor akses lembaga keuangan, tenaga kerja, pengalaman usahatani, usia, pendidikan, produktivitas, biaya usahatani, modal awal, harga biji kopi dan umur tanaman kopi berpengaruh signifikan terhadap pendapatan usahatani kopi. Pengujian secara parsial, hanya faktor tenaga kerja, jumlah pohon, biaya usahatani dan modal awal berpengaruh signifikan terhadap pendapatan usahatani kopi. Faktor tenaga, jumlah pohon dan modal awal berpengaruh positif sedangkan biaya usahatani berpengaruh negatif terhadap pendapatan.

\section{Saran}

Pemerintah diharapkan lebih giat dalam memberikan pendampingan dan sosialisasi tentang peningkatan produksi dari sisi hulu dan hilir, serta memberikan bantuan program pembiayaan kepada petani, agar selama pemeliharaan petani mampu untuk memberikan pupuk dan pemeliharaan sesuai dengan ajuran yang ditetapkan, yang pada akhirnya meningkatkan pendapatan. 


\section{DAFTAR PUSTAKA}

Audry, R. Joachim, Djuwendah, E. 2018. Analisis Pendapatan Usahatani Kopi Java Preanger pada Kelompok Tani Margamulya Desa Margamulya Kecamatan Pengalengan Bandung. Jurnal Ilmu Pertanian dan Peternakan. 6(1): 31-38.

[BPS] Provinsi Sumatera Barat. 2014. Sumatera Barat dalam Angka 2014. Padang: BPS Provinsi Sumatera Barat.

[BPS] Indonesia. 2017. Statistik Kopi Indonesia. Jakarta: Indonesia.

[BPS] Provinsi Sumatera Barat. 2019. Produksi Kopi Perkebunan Rakyat, 2007-2017.

Diambil

Agustus

2019.

https://sumbar.bps.go.id/dynamictable/2016/11/17/40/produksi-

kopi-perkebunan-rakyat-2007-2015.html.

Dewi, I. Novita, Awang, S. Afri, Andayani, W., Suryanto, P. 2018. Karakteristik Petani dan Kontribusi Hutan Kemasyarakatan (HKm) Terhadap Pendapatan Petani di Kulon Progo. Jurnal Ilmu Kehutanan. 12: 86-98.

Farmasari, Nasir, M, 2018. Analisis Faktor-faktor yang Mempengaruhi Pendapatan Petani Kopi di Kabuapten Bener Meriah. Jurnal Ilmiah Mahasiswa (JIM). 3(3): 275-283.

Gustiyana, H. 2004. Analisis Pendapatan Usahatani untuk Produk Pertanian. Salemba Empat: Jakarta.

Istianah, Hastuti, D., Prabowo R,. 2015. Faktor-faktor yang mempengaruhi tingkat pendapatan petani kopi (Coffea sp), (Studi Kasus di Kecamatan Jambu Kabupaten Semarang). MEDIAGRO. 11(2): 46-59.

Mankiw, N. G. 2000. Teori Makro Ekonomi. Jakarta: Erlangga.

Putri, Afrianingsih, Yusmarni, Paloma, C., Zakir, Z. 2018. Kinerja Faktor Produksi Kopi Arabika (Coffea arabica L.) di Kecamatan Lembah Gumanti, Kabupaten Solok, Sumatera Barat. Jurnal Teknologi dan Manajemen Agroindustri. 7(3): 189-197.

Sari, Irania. 2018. Analisis Faktor-faktor Sosial Ekonomi yang Mempengaruhi Perndapatan Petani Kopi (Studi Kasus: Desa Parau Sorat Kecamatan Sipirol Kabuapten Tapanuli Selatan. [Skripsi]. Medan. Fak. Pertanian. Univeristas Muhammdaiyah Sumatera Utara.

Soekartawi, 2002. Analisis Usahatani. Jakarta:UI Press.

Sukirno. 2003. Pengantar Teori Ekonomi Edisi Ketiga. Jakarta: PT Raja Grafindo Persada.

S. L. Neonbota \& S. J. Kune. 2016. Faktor-Faktor Yang Mempengaruhi Usahatani Padi Sawah Di Desa Haekto Kecamatan Noemuti Timur. Jurnal Agribisnis Lahan Kering. 1(3): 32-35. 
Supriyadi, Agus,. Wahyuningsih, S., Awami, S. N. 2014. Analisis Pendapatan Usahatani Kopi (Coffea sp) Rakyat di Kecamatan Limbangan Kabupaten Kendal. MEDIAGRO. 10(1): 1-13.

Yourdy, G. 2017. Analisis Faktor-faktor yang mempengaruhi Produksi Kopi Arabika di Sulawesi Selatan. [Skripsi]. Makassar. Departemen Ilmu Ekonomi. Fakultas Ekonomi dan Bisnis. Universitas Hasanuddin

Widyawati, R. Febriyastuti dan Pujiyono A. 2013. Pengaruh Umur, Jumlah Tanggungan Keluarga, Luas Lahan, Pendidikan, Jarak Tempat Tinggal Pekerja ke Tempat Kerja, dan Keuntungan terhadap curahan waktu wanita tani sektor pertanian di Desa Tajuk, Kecamatan Getasan, Kabupaten Semarang. Diponegoro Journal of Economics. 2(3):1-14.

314 | Cindy Paloma, Yusmarni, Ami Sukma Utami, Hasnah; Aksesibilitas... 